\title{
PERBANDINGAN KARAKTERISTIK PAPAN SEMEN DARI BATANG DAN CABANG KAYU ASAL HUTAN RAKYAT
}

\author{
Comparison of Cement Board Characteristics made from Stem and Branch of Community Forest Tree \\ Species
}

Suhasman ${ }^{\circledR}$

Lab. Pemanfaatan dan Pengolahan Hasil Hutan, Fakultas Kehutanan Universitas Hasanuddin, Jl. Perintis Kemerdekaan Km. 10 Tamalanrea, Makassar 90245

\begin{abstract}
Optimum utilization of raw materials is very important to overcome the limited raw materials supply. The objective of this study was to analyze the physical and mechanical properties of cement board made of stem and branch of tree. Materials used in this study were three wood species from community forest, namely; sengon (Paraserianthes falcataria), candlenut (Aleurites moluccana), and gmelina (Gmelina arborea). The raw materials taken from stem and branch of tree were converted into particle using hammer mill. Composition of particle, water, and cement weight based were $1: 1,25: 2,5$ for produce cement board, while density target of the boards were $0.85 \mathrm{~g} \mathrm{~cm}^{-3}$. To improve the board quality, $2.5 \% \mathrm{CaCl}_{2}$ based on cement weight was added. Mixed meterials then cold pressed during 24 hours and then conditioned for 1 month before tested. The research resuts are as follows: 1) Dimensional stability of cement board made from stem were superior compared to cement board made from branch of tree, 2) The MOR and Internal Bond of cement board have no clear different pattern between stem and branch of tree, 3) The MOE of cement board made from branch were higher compared to cement board made from stem of the three wood species.
\end{abstract}

Key words: Cement board, community forest, sengon, candlenut, gmelina

\section{PENDAHULUAN}

Papan semen adalah produk panel yang dibuat dengan menggunakan bahan baku partikel dari bahan lignosellulosa dan semen portland sebagai pengikat. Papan tersebut memiliki beberapa keunggulan yaitu tahan kelembaban, tahan api, jamur, dan serangga perusak. Selain itu, bahan pembuatan produk yang berupa partikel kayu juga menyebabkan produk ini sangat efisien terhadap penggunaan bahan baku, karena segala macam bentuk bahan baku dapat digunakan baik berupa log diameter besar, log diameter kecil, limbah kayu, serta bahan lignosellulosa lainnya.

Bentuk bahan baku berupa partikel juga mengindikasikan bahwa seluruh bagian pohon potensial untuk dimanfaatkan (the whole tree utilization). Hal ini merupakan keunggulan lain

Diterima: 16 September 2011; Disetujui: 8 Desember 2011

$\bowtie$ Penulis korespondensi (corresponding author): suhasman@yahoo.com dari produk papan semen, karena sejauh ini kebanyakan produk-produk kayu masih terfokus pada pemanfaatan bagian utama pohon, yaitu batang.

Akan tetapi papan semen memiliki kelemahan mendasar, yaitu tidak semua jenis kayu cocok digunakan sebagai bahan baku. Hal ini terutama disebabkan oleh keberadaan bahan ekstraktif dalam kayu yang dapat menghambat proses pengerasan semen (Semple \& Evans, 2000). Hal tersebut telah dibuktikan oleh Miller \& Moslemi (1991) yang menemukan bahwa kayu daun lebar (hardwood) di Amerika Serikat kurang sesuai sebagai bahan baku papan semen dibandingkan kayu daun jarum (softwood). Kenyataan tersebut menjadi tantangan bagi pengembangan produk papan semen di Indonesia karena sebagai daerah tropis, jenis-jenis kayu yang ada sebagian besar adalah jenis kayu daun lebar. Oleh karena itu dibutuhkan penelitian untuk mempelajari karakteristik papan semen yang dibuat dari berbagai jenis kayu yang banyak terdapat di Indonesia. Dalam hal ini, fokus penelitian perlu 
diarahkan pada usaha pemanfaatan jenis-jenis kayu dari hutan rakyat sebagai sumber bahan baku alternatif selain hutan alam.

Sebagai sumber bahan baku alternatif, potensi kayu hutan rakyat cukup besar. Di Sulawesi Selatan saja luas hutan rakyat mencapai 244.611 ha dan 53.671 ha diantaranya ditumbuhi oleh jenis kayu kemiri (A. moluccana) (Yunianti, 2002). Selain kemiri, jenis tanaman lain yang banyak ditanam dalam hutan rakyat di daerah ini adalah jati $(T$. grandis), sengon ( $P$. falcataria), dan gmelina ( $G$. arborea). Adapun luas hutan rakyat di seluruh Indonesia mencapai 1.265 .460 ha (Suhariyanto, 2003) dengan perkiraan potensi produksi 9,3 juta $\mathrm{m}^{3}$ thn ${ }^{-1}$ dengan jenis-jenis kayu seperti sengon, jati, mahoni, akasia, sengon dan kemiri.

Besarnya potensi hutan rakyat sebagaimana dikemukakan di atas, serta keberadaan 2 pabrik semen besar di Sulawesi Selatan yaitu PT. Semen Bosowa dan PT. Semen Tonasa masing-masing dengan kapasitas produksi 3,62 juta ton thn ${ }^{-1}$, dan 3,48 juta ton thn ${ }^{-1}$ merupakan potensi lokal yang dapatdikembangkan untukmengatasipermasalahan nasional. Namun demikian, oleh karena adanya masalah keterbatasan kesesuaian bahan baku, maka diperlukan investigasi kesesuaian dan kualitas produk yang dibuat dengan memanfaatkan bahan baku jenis kayu hutan rakyat sebagai bahan baku alternatif. Investigasi yang diperlukan tidak hanya terbatas pada bagian utama pohon, tetapi juga perlu mempertimbangkan pemanfaatan cabang pohon.

\section{BAHAN DAN METODE}

Tiga jenis kayu yang digunakan dalam penelitian ini adalah sengon ( $P$. falcataria), kemiri (A. moluccana), dan gmelina (G. arborea). Jenis kayu tersebut dipilih karena banyak dibudidayakan pada areal hutan rakyat di Sulawesi Selatan. Kayu kemiri diambil dari hutan rakyat di Barugae Kabupaten Maros, sedangkan kayu Sengon dan Gmelina diambil di areal hutan rakyat Mengkendek Kabupaten Tana Toraja Sulawesi Selatan.

Pohon dari masing-masing jenis dipisahkan bagian batang dan cabangnya. Bagian cabang yang diambil adalah yang berdiameter $5 \mathrm{~cm}$ atau lebih. Jenis kayu yang telah ditebang kemudian dibuang bagian kulitnya dan dibuat menjadi serpih lalu dikeringudarakan. Serpih tersebut selanjutnya dikonversi menjadi partikel dengan menggunakan hammer mill.
Komposisi partikel kayu, air, dan semen untuk pembuatan papan semen adalah $1: 1,25: 2,5$. Jenis semen yang digunakan adalah semen Portland tipe I produksi PT Semen Tonasa Pangkep Sulawesi Selatan. Komposisi ukuran partikel yang digunakan adalah 10 mesh untuk core dengan proporsi $70 \%$ dan ukuran partikel 20/40 mesh dengan proporsi 30 $\%$ untuk bagian face dan back.

Partikel yang telah disiapkan terlebih dahulu direndam air dingin selama 48 jam, dimana pada 24 jam pertama airnya diganti. Setelah 48 jam, partikel ditiriskan kemudian diangin-angingkan sampai mencapai kadar air pada kisaran 30-50\%. Partikel tersebut kemudian dicampur dengan air dan semen dengan perbandingan $1: 1,25: 2,5$. Selain bahan-bahan tersebut, maka ke dalam campuran ditambahkan pula katalis $\mathrm{CaCl}_{2} 2,5 \%$ berdasarkan berat semen.

Campuran bahan-bahan tersebut dibuat menjadi lembaran dengan ukuran $30 \times 30 \times 1 \mathrm{~cm}$ dengan target kerapatan $0,85 \mathrm{~g} \mathrm{~cm}^{-3}$. Lembaran kemudian dikempa dingin pada tekanan $15 \mathrm{kgf} \mathrm{cm}^{-2}$ kemudian lalu didiamkan selama 24 jam. Setelah itu papan semen yang terbentuk dikondisikan pada suhu ruang selama sebulan sebelum dipotong menjadi contoh uji.

Contoh uji yang telah dibuat selanjutnya diuji dengan merujuk pada Japanese Industrial Standard (JIS A 5417 1992). Parameter yang diuji meliputi sifat fisik yang terdiri atas: kerapatan, kadar air, daya serap air, dan pengembangan tebal, sedangkan sifat mekanik yang diuji meliputi keteguhan patah atau modulus of rupture (MOR), dan modulus elastisitas atau modulus of elasticity (MOE), serta keteguhan rekat.

\section{HASIL DAN PEMBAHASAN}

\section{Kerapatan}

Kerapatan papan semen yang dibuat dari bagian batang berkisar antara 0,75-0,80 $\mathrm{g} \mathrm{cm}^{-3}$, sementara kerapatan dari bagian cabang berkisar 0,77-0,90 $\mathrm{g} \mathrm{cm}^{-3}$. Kecuali papan semen dari batang sengon, seluruh jenis papan lainnya tidak memenuhi kerapatan sasaran sebesar $0,85 \mathrm{~g} \mathrm{~cm}^{-3}$. Kerapatan yang lebih rendah tersebut terjadi karena ternyata dalam proses setting selama 24 jam, ikatan semen belum cukup kuat, sehingga pada saat tekanan dilepaskan papan masih mengalami gejala spring back yang membuat tebalnya mengalami peningkatan. Akibatnya, pada berat yang sama, 


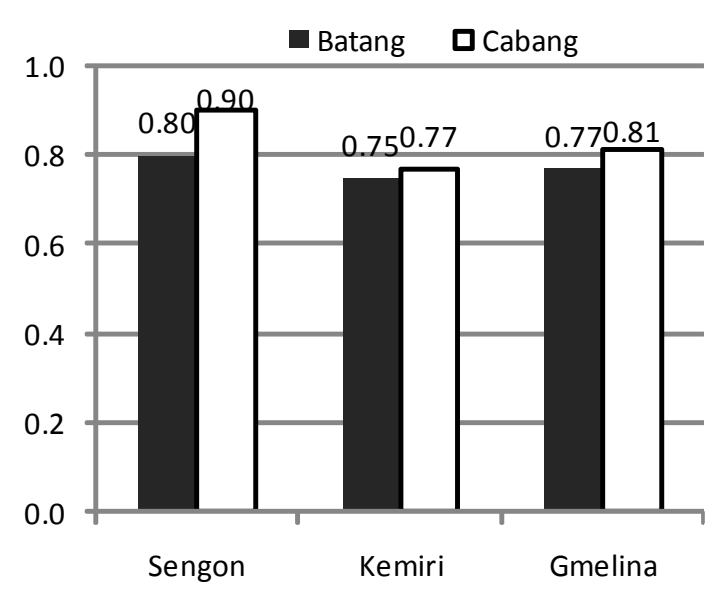

Gambar 1. Kerapatan papan partikel $\left(\mathrm{g} / \mathrm{cm}^{3}\right)$

volume papan mengalami peningkatan, sehingga berimplikasi pada penurunan kerapatan. Sebaran kerapatan masing-masing jenis papan disajikan pada Gambar 1. Gambar tersebut mengindikasikan kecenderungan kerapatan papan yang lebih tinggi pada papan yang dibuat dari cabang dibandingkan dengan batang, meskipun perbedaannya relatif kecil, khususnya pada kayu kemiri.

\section{Kadar Air}

Jenis kayu kemiri memiliki kerapatan 0,29$0,32 \mathrm{~g} \mathrm{~cm}^{-3}$, terendah dibandingkan kayu sengon dan gmelina yang masing-maing memiliki kisaran kerapatan 0,34-0,40 $\mathrm{g} \mathrm{cm}^{-3}$ dan 0,41-0,45 $\mathrm{g} \mathrm{cm}^{-3}$ (Suhasman et al., 2007). Dengan demikian kayu kemiri akan lebih volumenous dibandingkan jenis kayu lainnya sehingga memungkinkan lebih banyak permukaan kayu yang terekspos pada saat digunakan sebagai bahan baku papan semen. Banyaknya bagian kayu yang terekspos

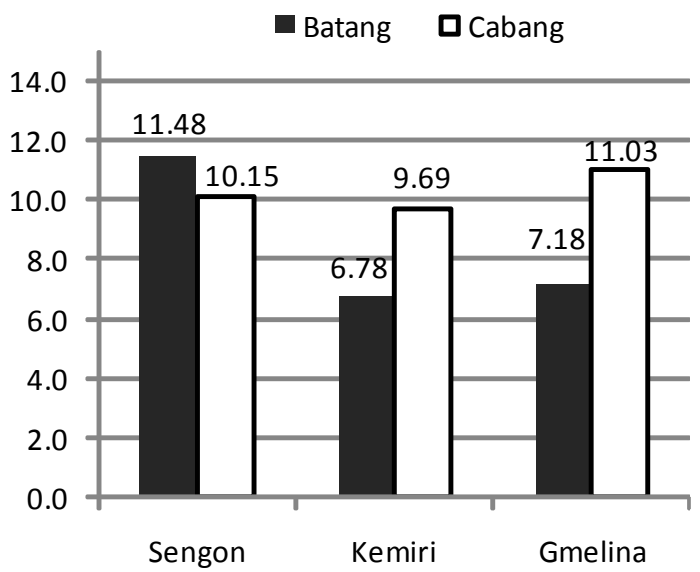

Gambar 2. Kadar air papan partikel (\%) tersebut diasumsikan akan membuat kadar air keseimbangannya lebih tinggi. Akan tetapi hasil penelitian ini menunjukkan bahwa kadar air papan semen dari jenis kayu kemiri ternyata merupakan kadar air terendah dibandingkan jenis papan lainnya. Oleh karena itu dapat disimpulkan bahwa variasi kadar air ini tidak berhubungan secara langsung dengan kerapatan papan. Tampaknya perbedaan kadar air tersebut disebabkan oleh jumlah air terikat yang lebih banyak pada jenis kayu berkerapatan lebih tinggi, sehingga pada saat pengujian kadar air papanpun cenderung lebih tinggi. Selanjutnya, dilihat dari variasi kadar air antara batang dan cabang, tampak bahwa tidak terdapat perbedaan yang signifikan, serta tidak memiliki kecenderungan tertentu. Sebagaimana disajikan pada Gambar 2, papan dari batang kayu sengon memiliki kadar air yang lebih tinggi dibandingkan cabangnya, akan tetapi kedua jenis kayu lainnya memiliki nilai yang sebaliknya. Dengan demikian dapat disimpulkan bahwa secara umum, bagian cabang dan batang tidak berpengaruh terhadap kadar air keseimbangan papan.

\section{Daya Serap Air}

Berbeda dengan nilai kadar air, sifat daya serap air papan memiliki kecenderungan yang sama ditinjau dari asal bahan bakunya. Bagian batang pohon menghasilkan daya serap air yang lebih tinggi dibandingkan bagian cabang pada ketiga jenis kayu. Daya serap air pada papan semen menunjukkan jumlah air yang masuk ke dalam papan setelah papan tersebut direndam selama 24 jam. Fenomena terserapnya air ke dalam papan ini dapat melalui dua mekanisme, yaitu air terserap ke dalam partikel kayu yang permukaannya terekspos, atau air mengisi ruang-ruang kosong yang terdapat dalam papan. Perbedaan daya serap air antara bagian cabang dan batang, tampaknya berhubungan dengan kerapatan. Meskipun perbedaan kerapatan papan bagian batang dengan cabang relatif kecil, akan tetapi hal ini diduga berpengaruh terhadap daya serap airnya. Sebagaimana disajikan pada Gambar 1, bagian cabang cenderung memiliki kerapatan yang lebih tinggi dibandingkan dengan batang. Hal ini mengindikasikan bahwa ruang kosong yang terdapat dalam papan semen dari cabang cenderung lebih kecil dibandingkan dengan papan dari batang. Hal inilah yang menyebabkan daya serap air pada papan semen yang terbuat dari 


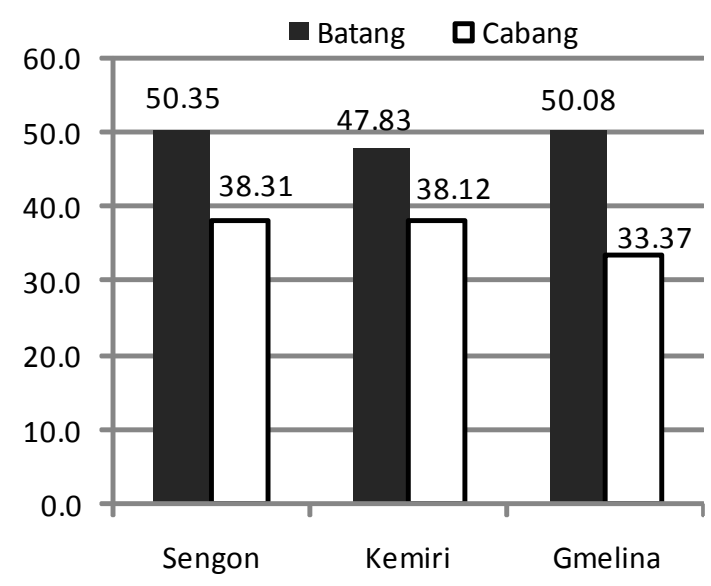

Gambar 3. Daya serap air (\%)

cabang lebih rendah. Sebaran nilai daya serap air masing-masing jenis papan yang dibuat disajikan pada Gambar 3.

\section{Pengembangan Tebal}

Pengembangan tebal papan semen bagian cabang cenderung lebih tinggi dibandingkan dengan pengembangan tebal bagian batang. Nilai pengembangan tebal bagian cabang berkisar antara 3,07-4,32 \% sementara bagian batang hanya berkisar 0,90-1,78\%. Hal tersebut menunjukkan bahwa papan semen yang dibuat dari bagian batang memiliki stabilitas dimensi yang 1,7-4,8 kali dibandingkan papan semen dari bagian cabang. Fenomena pengembangan tebal ini dapat terjadi akibat pengembangan partikel karena penyerapan air maupun akibat kurang kuatnya ikatan perekat semen.

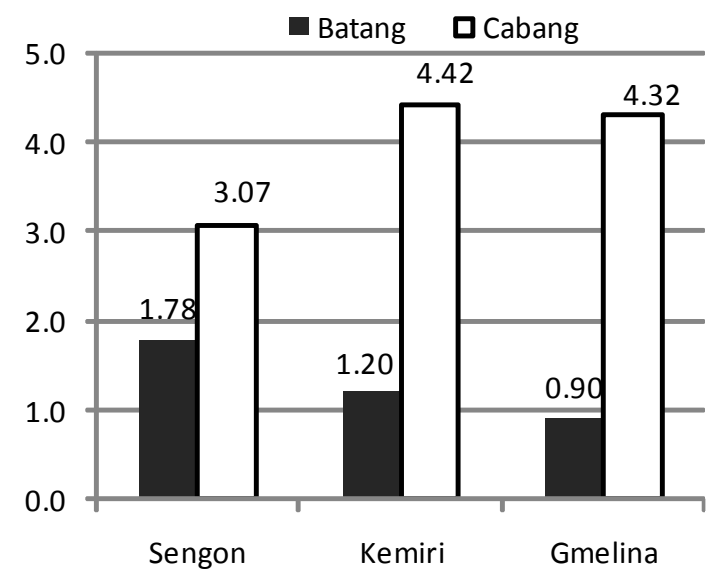

Gambar 4. Pengembangan tebal papan (\%)

\section{Keteguhan Patah}

Sebaran nilai keteguhan patah masing-masing jenis papan disajikan pada Gambar 5. Data pada gambar tersebut menunjukkan bahwa papan semen dari bagian batang kayu sengon memiliki keteguhan patah tertinggi, sedangkan keteguhan patah terendah diperoleh pada papan yang dibuat dari batang kayu kemiri. Apabila diamati, maka akan tampak bahwa perbandingan keteguhan patah papan semen antar bagian batang dengan cabang tampak tidak memiliki kecenderungan tertentu di antara ketiga jenis kayu. Batang kayu sengon menghasilkan papan dengan keteguhan yang lebih baik dibandingkan dengan cabangnya, demikian halnya kayu gmelina, meskipun selisihnya relatif kecil. Akan tetapi jenis kayu kemiri memiliki keteguhan patah yang lebih baik pada papan yang dibuat dari cabang, dibandingkan dengan batang. Dengan demikian dapat disimpulkan bahwa sesungguhnya tidak terdapat perbedaan tertentu antara papan yang terbuat dari cabang dengan batang, ditinjau dari sifat keteguhan patahnya.

\section{Modulus Elastisitas}

Sebaran nilai modulus elastisitas papan disajikan pada Gambar 6. Fenomena yang tampak pada gambar tersebut menunjukkan bahwa papan semen yang terbuat dari cabang cenderung memiliki nilai modulus elastisitas yang lebih tinggi dibandingkan papan dari bagian batang. Kecenderungan ini berlaku untuk ketiga jenis kayu. Modulus elastisias ini merefleksikan kemampuan bahan untuk menahan perubahan bentuk, dalam hal ini defleksi, apabila menerima beban dalam jumlah tertentu. Hal ini menunjukkan bahwa papan

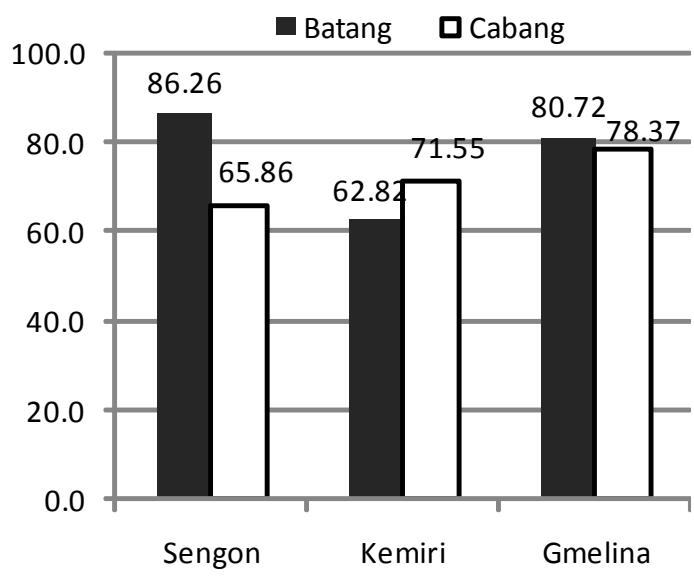

Gambar 5. Keteguhan patah $\left(\mathrm{kgf} \mathrm{cm}^{-2}\right)$ 


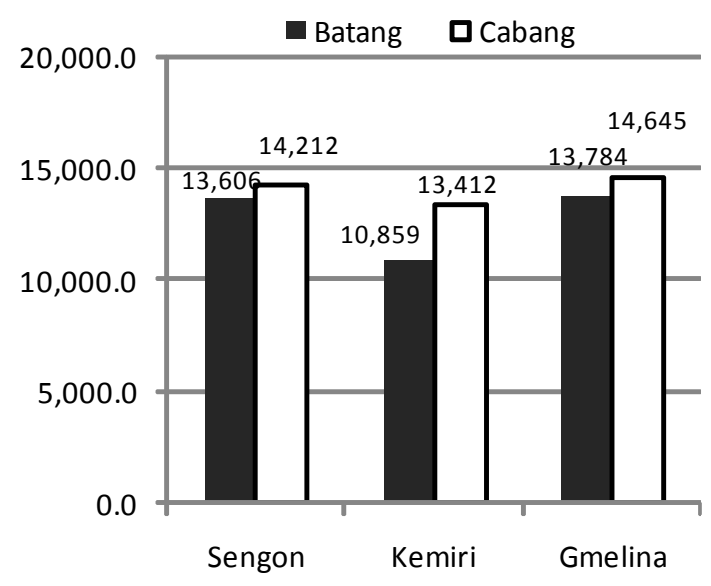

Gambar 6. Modulus elastisitas $\left(\mathrm{kgf} \mathrm{cm}^{-2}\right)$

semen yang terbuat dari bagian cabang pohon akan memiliki kondisi yang lebih stabil pada saat menerima beban. Oleh karena dalam penggunaan, salah satu permasalahan pada papan komposit, termasuk papan semen, adalah nilai modulus elastisitas yang rendah, maka hasil penelitian ini memberikan indikasi yang baik pada salah satu parameter penting dari sifat-sifat papan semen. Hasil ini menunjukkan bahwa penggunaan cabang pohon sebagai bahan baku pembuatan papan semen ternyata tidak menimbulkan dampak yang merugikan terhadap modulus elastisitas papan.

\section{Keteguhan Rekat}

Meskipun papan semen dari kayu kemiri memiliki keteguhan patah yang relatif lebih rendah dibandingkan jenis kayu lainnya, akan tetapi dalam hal keteguhan rekat(internalbond), kayu kemirijustru memiliki kekuatan terbaik. Selanjutnya ditinjau dari perbedaan keteguhan rekat antara bagian batang dengan cabang, maka tampak bahwa tidak terdapat kecenderungan tertentu. Meskipun papan dari jenis cabang kayu sengon memiliki nilai keteguhan rekat yang lebih tinggi dibandingkan batangnya, akan tetapi ternyata kedua jenis kayu lainnya memiliki fenomena sebaliknya. Keteguhan rekat papan dari bagian batang kayu kemiri dan kayu gmelina cenderung lebih tinggi dibandingkan papan semen dari bagian cabangnya.

Hasil-hasil penelitian sebagaimana diuraikan di atas menunjukkan bahwa karakteristik papan semen yang dibuat dari bagian batang dan cabang pohon relatif sama. Meskipun untuk parameter tertentu tampak bahwa bagian batang menghasilkan papan dengan kualitas yan lebih

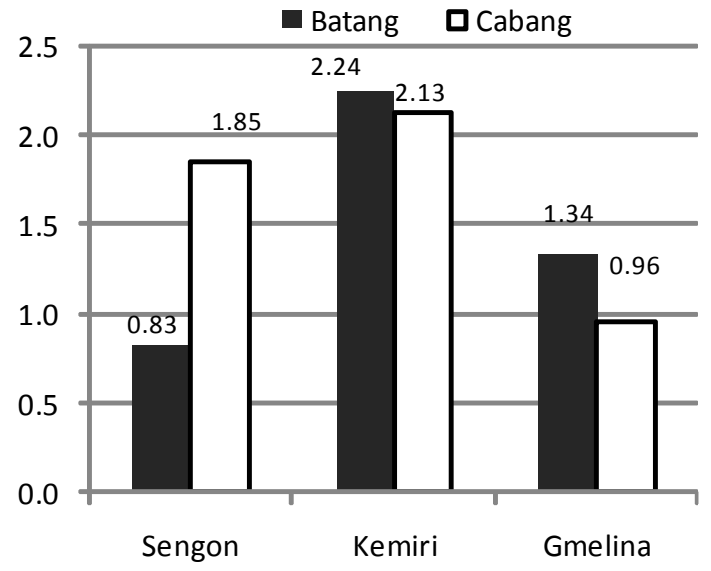

Gambar 7. Internal bond ( $\left.\mathrm{kgf} \mathrm{cm}^{-2}\right)$

baik, akan tetapi untuk parameter lainnya hasilnya berbeda. Fenomena demikian juga ditemukan pada papan partikel yang dibuat dengan menggunakan perekat Melamin formaldehida (Suhasman et al., 2008). Dalam penelitian tersebut juga disimpulkan bahwa penggunaan bagian cabang pohon dalam pembuatan papan partikel tidak memberikan pengaruh negatif terhadap kualitas papan.

\section{KESIMPULAN}

Hasil penelitian menunjukkan bahwa penggunaan bagian cabang pohon dalam pembuatan papan semen ternyata tidak memberikan respon negatif terhadap sifat-sifat papan semen, kecuali dalam hal stabilitas dimensi. Selain itu, dari hasil penelitian ini juga dapat disimpulkan bahwa penggunaan ketiga jenis kayu sebagai bahan baku papan semen menghasilkan papan semen dengan kualitas yang relatif sama. Dengan demikian, secara umum, jenis-jenis kayu dari hutan rakyat tersebut memungkinkan untuk dimanfaatkan sebagai bahan baku papan semen, baik dari bagian batang, maupun cabangnya.

\section{UCAPAN TERIMA KASIH}

Penulis mengucapkan terima kasih kepada saudara Verdiantoro B.S. atas bantuan teknisnya dalam melaksanakan penelitian ini.

\section{DAFTAR PUSTAKA}

Miller, D.P. and A.A. Moslemi. 1991. Wood Cement Composite: Species and Heartwood-Sapwood Effect on Hydration and Tensile Strength. Forest Products Journal, Volume 41 No. 3. Forest Products Research Society, Madison, WI, USA. 
Purnama B. M., A. Justianto, R. Tjandrakirana and K. B. Prihatno, 2003. Produksi Kayu Bulat Indonesia : Potensi dan Permasalahannya. Di dalam : Daryanto H, D S Sukardi, AZ Rosyadi, editor. Prosiding Diskusi Panel "Menyongsong Industri Perkayuan yang Lestari. Kerjasama antara Puslitbang Sosek, Badan Litbang Kehutanan Departemen Kehutanan-ITTO-Badan Revitalisasi Industri Kehutanan (BRIK); Bogor, 24 April 2003.

Semple, K.E. and P.D. Evans. 2000. Screening Inorganic Additives for Ameliorating the Inhibition of Hydration of Portland Cement by the Heratwood of Acacia mangium in Wood-Cement Composites in the Asia-Pacific Region. Proceeding of a Workshop Held at Rydges Hotel, Canberra Australia, 10 Desember 1000.
Suhasman, A D Yunianti, M Y Massijaya and Y S Hadi, 2007. Pengembangan Papan Komposit Berkualitas Tinggi dari Kayu Hutan Rakyat dan Limbah Kertas Kantong Semen. Laporan Penelitian Hibah Pekerti. Universitas Hasanuddin Makassar.

Suhasman, A D Yunianti, M Y Massijaya and Y S Hadi, 2008. Performance of Composite Board Manufactured from Stem and Branch of Tree. Proceeding of International Symposium on Wood Science and Technology IAWPS 2008, Harbin, China September 27th 29th, 2008.

Yunianti A D, 2002. Kemiri (Aleurites moluccana), Perennial, Media Informasi, Sosialisasi, dan Komunikasi HKm, Jurusan Kehutanan Universitas Hasanuddin. Edisi 2 Tahun I, Juni 2002. Pp 30-31. 